\section{Construction and Use of an Inexpensive Rain Gauge ${ }^{1}$}

PAUL D. OHLENBUSCH

Research Associate, Department of Range Science, Texas A\&M University, College Station.

\section{Highlight}

An inexpensive, wind-proof rain gauge was devised for measuring precipitation at remote locations. The gauge can be constructed from a funnel, gasoline can and assorted lumber and metal. Gauges in use over one year have withstood winds in excess of 50 miles per hour. Ease of installation and minimal maintenance requirements make the gauge desirable for remote or inaccessible locations that are visited infrequently. Protection from livestock may be necessary if rubbing is a problem.

An inexpensive rain gauge with wind-proof stand was developed while establishing studies to characterize the phenology of vegetation in West Texas. The gauges were to be left for periods of up to three weeks. Various gauges were considered but found to be unacceptable. The small glass vial type, while being less expensive, limited data collection to the frost-free period. Official Weather Bureau gauges were considered to be too expensive.

${ }^{1}$ Published with approval of the Director of the Texas Agricultural Experiment Station as TA9424. Received October 8, 1971.
Haas and Morton'2 designed and used a gauge made from a tractor funnel and a gasoline can in Idaho, and found it accurate enough for year-round research studies. The can was partially buried in the ground to prevent being overturned. A later version used by Haas in East Texas sat on a platform and was supported by a metal stake.

The reliability of the gauge was studied by Haas ${ }^{3}$. Two of the funnelcan gauges and two official Weather Bureau gauges were compared at College Station, Texas. One of each type of gauge was located on two sites 150 yards apart. Measurements were made with a calibrated ruler for the Weather Bureau gauges. The funnel-can gauges were measured using a graduated cylinder. Measurements were made within twelve hours after each rain from May through August. Thirty-two measurements were made ranging from 0.11 to 1.93 inches. The mean rainfall measurements at each site were the same for both types of gauges (Site No. 10.67 inches; Site No. 2-0.69 inches).

The purpose of this article is to describe a gauge based on the one built by Haas and Morton with a wind-proof stand (Fig. 1).

\section{Construction, Installation and Use}

A list of materials for the construction of an inexpensive rain gauge is found in Table 1 . The rain gauge is

${ }^{2}$ Haas, R. H., and H. L. Morton. 1955. Annual Report, Weed Investigation Section, Agr. Res. Serv., U.S. Dep. Agr.

${ }^{3}$ Haas, R. H. Unpublished data. assembled by cutting out the center of the filler cap of the gasoline can and then brazing the funnel spout into it. The cap gasket is cut to form a ring to seal the cap when the cap and can are assembled.

The stand is made by nailing four pieces of $1 \times 12$ inch lumber into an open-ended box with inside measurements of approximately 11 inches on a side. The two pieces of $2 \times 4$ inch lumber are nailed into one end of the box flat leaving an opening approximately 3 inches wide and 11 inches long. The stands can be painted white for protection from the weather.

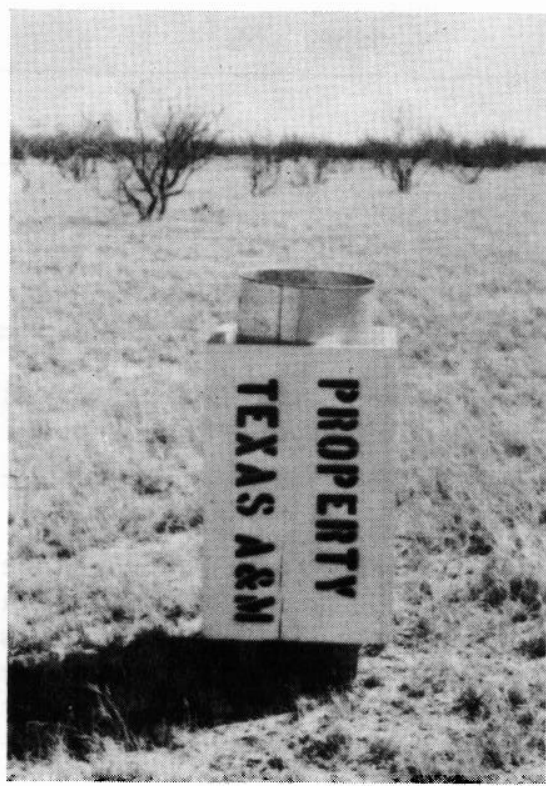

Fig. 1. The assembled rain-snow gauge in service. 
The gauge is installed by inserting the anchor pins through the holes drilled in the $2 \times 4$ lumber from inside the box. Legs are then put over the anchor pins. A steel post driver or a piece of pipe and hammer are then used to drive the pins into the soil until snug. The stand is leveled by driving the appropriate rod further into the soil. (Note: The pin should not be raised in an attempt to level the stand.) The assembled gauge is then lowered into the stand, whereupon approximately four inches of the funnel will extend above the stand. Care should be taken to keep the handle of the gasoline can on the side opposite the pouring spout. This will aid in removing and reading the gauge.

To prevent evaporation and freezing, diesel oil and antifreeze were used.

Table 1. List of materials needed to assemble an inexpensive, wind-proof rainsnow gauge for collection of precipitation data in remote locations.

\begin{tabular}{|c|c|}
\hline No. & Item and Description \\
\hline 1 & $\begin{array}{l}\text { Funnel, tractor-type (approximately } 10 \text { inch diameter with five inch verti- } \\
\text { cal sides) }\end{array}$ \\
\hline 1 & Two gallon gasoline can with center filling cap \\
\hline 4 & $1^{\prime \prime} \times 12^{\prime \prime} \times 20^{\prime \prime}$ pine lumber boards \\
\hline 2 & $\begin{array}{l}2^{\prime \prime} \times 4^{\prime \prime} \times 11^{\prime \prime} \text { pine lumber boards (one with a } 3 / 4 \text { inch hole drilled in } \\
\text { center of } 4 \text { inch side, the other with a } 3 / 4 \text { inch hole drilled } 2 \frac{1}{2} \text { inches } \\
\text { from each end of the } 4 \text { inch side) }\end{array}$ \\
\hline 3 & Legs, $11 / 2^{\prime \prime} \times 4^{\prime \prime}$ pipe \\
\hline 3 & $\begin{array}{l}\text { Anchor pins, } 3 / 4^{\prime \prime} \times 18^{\prime \prime} \text { steel or iron rods with a washer welded to one } \\
\text { end } \\
\text { No. } 8 \text { box nails }\end{array}$ \\
\hline
\end{tabular}

From May 1 to November 1 , the frostfree period, $400 \mathrm{ml}$ of No. 2 diesel oil was kept in the gaugc. The gauges were read and the diesel oil changed at least every three weeks when the temperature exceeded $95 \mathrm{~F}$. At these temperatures approximately $5 \%$ of the diesel oil was lost each week. During the remainder of the year, $400 \mathrm{ml}$ of ethlyene-glycol antifreeze was maintained in the gauge. A small amount of diesel oil may be kept in the gauge also. At temperatures above $10 \mathrm{~F}$, the antifreeze will prevent precipitation of 1.5 inches from freezing. The amount of antifreeze used was based on the expected low temperature and precipitation. Antifreeze need not be replaced unless diluted or high temperatures are experienced.

Precipitation is measured with a graduated cylinder. A $500 \mathrm{ml}$ graduate was convenient for our conditions. The volume of precipitation is determined by making the measurement at the oilwater interface and by subtracting the amount of antifreeze from the total volume in the gauge. To determine the volume of precipitation needed to make an inch of precipitation the following formula was used4:

$\mathrm{ml}$ per inch of precipitation = $\mathrm{r}^{2}(51.4814)$

where $r=$ the radius of the funnel from the center of the lip.

\section{Discussion}

Materials cost approximately $\$ 9.00$, plus one hour labor, for each gauge. Six of the gauges were made and installed in early 1970 and all have withstood winds in excess of 50 miles per hour on at least two occasions. One gauge was damaged by cattle using it as a "rubbing-post." A fence made from four 6-foot steel posts, 50 feet of 36-inch sheep wire and 50 feet of barbed wire erected in a square around the gauge has prevented further damage. Four other gauges placed in pastures with cattle have not been damaged.

The design of the stand (i.e., the open bottom) allows ventilation, keeping the liquid in the gauge cool. This ventilation probably helps reduce evaporation.

\footnotetext{
${ }^{4}$ Derived as follows: $(3.1416) \times$ (radius of funnel $)^{2} \times$ (l inch depth in funnel) $\times(16.387) \mathrm{ml}$ per inch of precipitation $=\mathrm{r}^{2}(51.4814)$.
} 